ACTA MYCOLOGICA

Vol. 42 (2): 235-238

2007
Dedicated to Professor Alina Skirgietto

on the occasion of her ninety-fifth birthday

\title{
New for Poland and rare species of anamorphic fungi
}

\author{
BEATA CZERNIAWSKA
}

Department of Plant Pathology, University of Agriculture, Słowackiego 17, PL-71-434 Szczecin

Czerniawska B.: New for Poland and rare species of anamorphic fungi. Acta Mycol. 42 (2):235-238, 2007.

Morphological characters of and disease symptoms caused by five fungal species parasitizing on plants of the Słowiański Park and the Drawieński National Park (both located in north-western Poland) are presented. Of the species, Ramularia celastri and Ascochyta irpina are new for Poland, and Ascochyta geraniicola, Phyllosticta caricis and Septoriella junci have earlier rarely been found in this country. Moreover, the latter three fungi were found on plants so far not reported in the literature to be their hosts. Finally, the known distribution of the fungi characterized in both Poland and the other regions of the world is presented.

Key words: parasitic fungi, Drawieński National Park, Słowiański Park

\section{INTRODUCTION}

In the years 2002 and 2004, the occurrence of microscopic fungi on plants of the Słowiański Park (SP) in Gorzów Wielkopolski and the Drawieński National Park (DNP) was investigated. Among the fungal species identified two are new for Poland, and three were so far reported from only a few sites of this country. Additionally, they were associated with host plants earlier not listed in the literature.

\section{MATERIALS AND METHODS}

Fragments of diseased plant organs were collected in PS and DNP in the years 2002 and 2004, respectively. The plant samples were collected once a month, from August to November. A total of 90 diseased plant organs were sampled. The plant species were identified according to Szafer, Kulczyński and Pawłowski (1969). Their nomenclature follows that of Mirek et al. (1995).

In the laboratory, the characters of disease symptoms and their distribution on the plant organs collected were first determined. Then, to determine the diagnostic properties of the fungi accompanying the disease symptoms, thin cuttings from a 
transverse section of the organs hosting of a given fungus were made using a safety razor and the OLYMPYS SZ40 dissecting microscope. They were subsequently transferred to a drop of lactic acid placed on a microscope slide, covered with a cover glass, and observed under the OLYMPUS CX21 compound microscope. Fungi were identified according to Brande n burge r (1985), B ra un (1998), Ellis and Ellis (1987), Sałata (2002) and Sutton (1980). The authors of the fungal names are as those presented at the URL web page http://www.indexfungorum.org/ AuthorsOfFungalNames.htm. Microphotographs were recorded on a Sony CDD DXC-390 colour video camera coupled to the OLYMPUS BX50 compound microscope equipped with Nomarski differential interference contrast optics. The floral materials and preserved specimens of the fungi presented here are deposited at the Department of Plant Pathology University of Agriculture in Szczecin.

Explanation: ! - species new to Poland

\section{RESULTS}

! Ramularia celastri Ellis et G. Martin

Spots randomly distributed on the upper leaf side, circular to subcircular, grey brown, 3-7 mm diam, with a deep-violet border (Fig. 1a). Sporulation scanty, creamwhite, on the under side of the spots. Conidia hyaline, 10-28 x 2-3 um, 0-1-2-septate. On Euonymus europaeus L., 10.08, 11.09 and 07.10.2004, DNP.

Distribution. Poland. This is the first report of the occurrence of $R$. celastri in Poland. Other Regions. According to Bra un (1998), R. celastri was recorded on E. europaeus growing in Montonegro (Yugoslavia).

REMARKs. The conidia of $R$. celastri found in DNP were slightly shorter than those characterized by Braun (1998; 8-35 x 2-4.5 $\mu \mathrm{m})$.

! Ascochyta irpina Sacc. et Trotter

Spots randomly distributed on the upper leaf side, subcircular, pale yellow, 10$15 \mathrm{~mm}$ diam (Fig. 1b). Pycnidia flattened, brown, 92-120 $\mu \mathrm{m}$ diam, with a circular ostiolum, immersed in the leaf tissue (Fig. 1c-e). Conidia pale olive, ellipsoid, with rounded tips, 2-celled, not constricted at the septum, 10-12 x 4-5 $\mu$ m (Fig. 1f). On Quercus rubra L., 11.11.2002, SP.

Distribution. Poland. No literature report exists of the finding of $A$. irpina in Poland. OTHER REGIONs. Italy (Petrak 1920).

Remarks. Mel'nik, Braun and Hagedor (2000) excluded $A$. irpina from the genus Ascochyta. However, they did not accommodate it to any known fungal group.

Another species of the genus Ascochyta affecting leaves of Quercus spp. is $A$. quercus Sacc. et Speg. The main character separating the two fungi is colour of its conidia. Conidia of $A$. irpini are coloured, whereas those of $A$. quercus are hyaline.

Ascochyta quercus has been found associated with leaves of $Q$. robur L. growing in the Wilanów Park in Warsaw (Sała ta 2002).

Ascochyta geraniicola Siemaszko

Spots randomly distributed on the upper leaf side, subcircular, brown, 3-5 mm diam (Fig. 2a). Pycnidia globose, brown, 120-200 $\mu \mathrm{m}$ diam, with a circular ostiolum, 
immersed in the leaf tissue. Conidia hyaline, ellipsoid, with rounded tips, 2-celled, not constricted at the septum, 7.5-10 x 2.5-5 um (Fig. 2b). On Geranium sylvaticum L., 08.08.2004, DNP.

Distribution. Poland. On G. palustre L.: Rajec near Radom and Sądkowa near Jasło (Sałata 2002). This paper is the first report of the occurrence of $A$. geraniicola on G. sylvaticum growing in Poland. OTHER REgIONs. On G. sylvaticum: Asia (Mel'nik et al. 2000).

REMARKs. The pycnidia and conidia of the specimens of $A$. geranicola found by the author of this paper are similar in size to those given by S a ł a t a (2002; pycnidia: 100-160 um diam; conidia: 8-10 x 3-3.5 $\mu \mathrm{m}$ ).

\section{Septoriella junci (Desm.) B. Sutton}

Spots randomly distributed on the upper leaf side, ellipsoid, pale brown, with a brown border, 3-4 mm diam (Fig. 2c). Pycnidia globose, dark brown, 50-70 um diam, with a circular ostiolum, immersed in the leaf tissue (Fig. 2c-e). Conidia pale brown, filiform, straight, with rounded tips, 3-5-septate, not constricted at the septa, 55-70 x 2-3 $\mu \mathrm{m}$ (Fig. 2f). On Juncus bufonius L., 08.08. and 10.09.2004, DNP.

Distribution. Poland. On J. conglomeratus L. and J. effusus L.: Słowiński National Park (Ad amska 2005). OTHER REGions. On J. effusus and J. maritimus Lam.: Germany and France (Sutton 1980).

REMARKs. This paper for the first time informs of $J$. bufonius to be a host plant of S. junci.

\section{Phyllosticta caricis (Fuckel) Sacc.}

Spost randomly distributed on the upper leaf side, ellipsoid, dark brown, 3-4 x 2-3 $\mathrm{mm}$ diam. Pycnidia globose, dark brown, 60-70 $\mu \mathrm{m}$ diam, with a circular ostiolum, immersed in the leaf tissue (Fig. 2g-h). Conidia hyaline, ovoid, with rounded tips, 1-celled, 3-4 x 2 m (Fig. 2h). On Carex pilulifera L., 10.09 and 11.09.2004, DNP.

Distribution. Poland. On C. pilosa Scop.: Białowieża National Park (Mułe n ko 1996; Mułenko, Chlebicki 1992; on C. acutiformis Ehrh., C. arenaria L., and C. pseudocyperus L.: Słowiński National Park (Adamska 2005).

REMARKS. This paper is the first report of $C$. pilulifera to harbour $P$. caricis.

\section{REFERENCES}

Adamska I. 2005. Fungal species new in Poland on Carex i Juncus. Acta Mycol. 40 (1): 19-24.

Branden burge r W. 1985. Parasitische Pilze an Gefäßpflanzen in Europa. G. Fischer Verlag, StuttgartNew York.

Braun U. 1998. A monograph of the Cercosporella, Ramularia and allied genera (phytopathogenic Hyphomycetes). IHW-Velag.

E11 is M. B., E1lis J. P. 1987. Microfungi on land plants. An Identification Handbook. Croom.

Mel'nik V. A., Braun U., Hagedor G. 2000. Key to the fungi of the genus Ascochyta Lib. (Coelomycetes). Parey Buchverlag Berlin.

Mirek Z., Piękoś-Mirkowa H., Zając A., Zając M. 1995. Vascular plants of Poland. A checlist. W. Szafer Institute of Botany, Polish Academy of Sciences, Kraków.

Mułenko W. 1996. Annex. Parasitic microfungi and their hosts collected on the study area. (In:) J. B. Faliński, W. Mułenko (eds). Cryptogamus plants in the forest communites of Białowieża National Park. Functional groups analysis and generalsynthesis (Project CRYPTO). Phytocenosis 8 (N.S.) Archiv. Geobot. 6: 55-65. 
Mułenko W., Chlebicki A. 1992. Cryptogamus plants in the forest communites of Białowieża National Park. Check-list of cryptogamus and seminal plant species recorder during the period 19871991 on the permanent plot V-100. (Project CRYPTO). Phytocenosis 4 (N.S.) Archiv. Geobot. 6.

Petrak F. 1920. Pilze 1920. Ohne die Schizomyceten and Flechten. http://www.indexfungorum.org/Names/NamesRecord.asp?RecordID $=268158$.

Sała a B. 2002. Polskie gatunki grzybów mitosporowych z rodzaju Ascochyta. Wyd. UMCS. Lublin.

Sutt on B. C. 1980. The Coelomycetes. Fungi Imperfecti with Pycnidia Acervuli and Stromata. Commonwealth Mycological Institute. Kew Surrey. England.

Szafer W., Kulczyński S., Pawłowski B. 1969. Rośliny polskie. PWN. Warszawa.

\section{Nowe dla Polski i rzadkie gatunki grzybów anamorficznych}

\section{Streszczenie}

Przedstawiono cechy morfologiczne pięciu gatunków grzybów pasożytujących na roślinach Słowianskiego Parku położonego w Gorzowie Wielkopolskim i Drawieńskiego Parku Narodowego oraz objawy chorobowe przez nie powodowane. Spośród tych gatunków Ramularia celastri i Ascochyta irpina są nowe dla Polski, a Ascochyta geraniicola, Phyllosticta caricis i Septoriella junci wcześniej znajdywano rzadko w tym kraju. Co więcej ostatnie trzy gatunki znaleziono na roślinach dotychczas nie podawanych w literaturze, że są ich gospodarzami. W końcu przedstawiono poznane rozmieszczenie scharakteryzowanych grzybów zarówno w Polsce, jak i w innych regionach świata. 


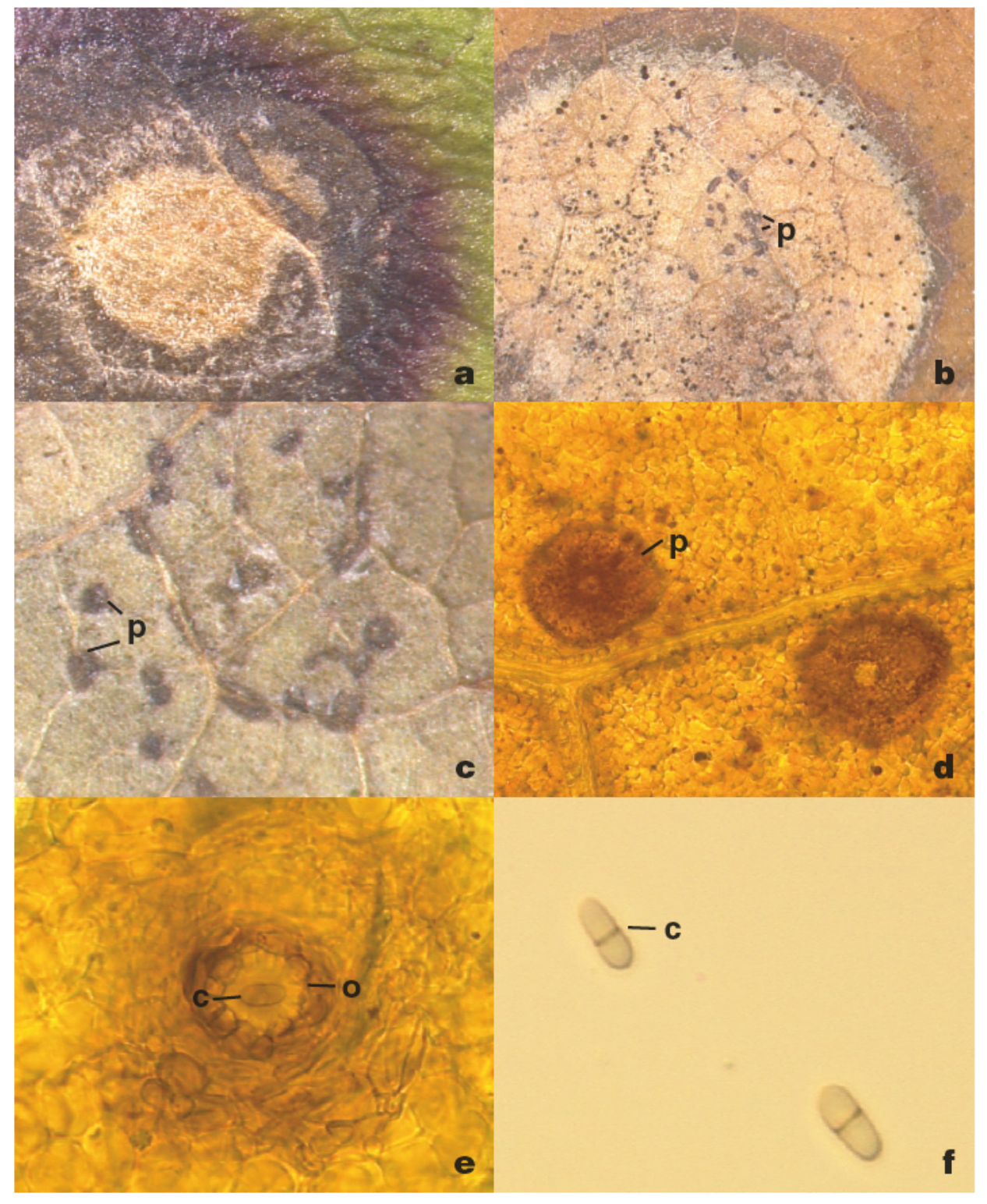

Fig. 1. Ramularia celastri on a leaf of Euonymus europaeus (a); Ascochyta irpina: pycnidia on a leaf of Quercus rubra (b-d), 1-celled conida (e-f); c-conidia, o-ostiolum, p-pycnidium. 


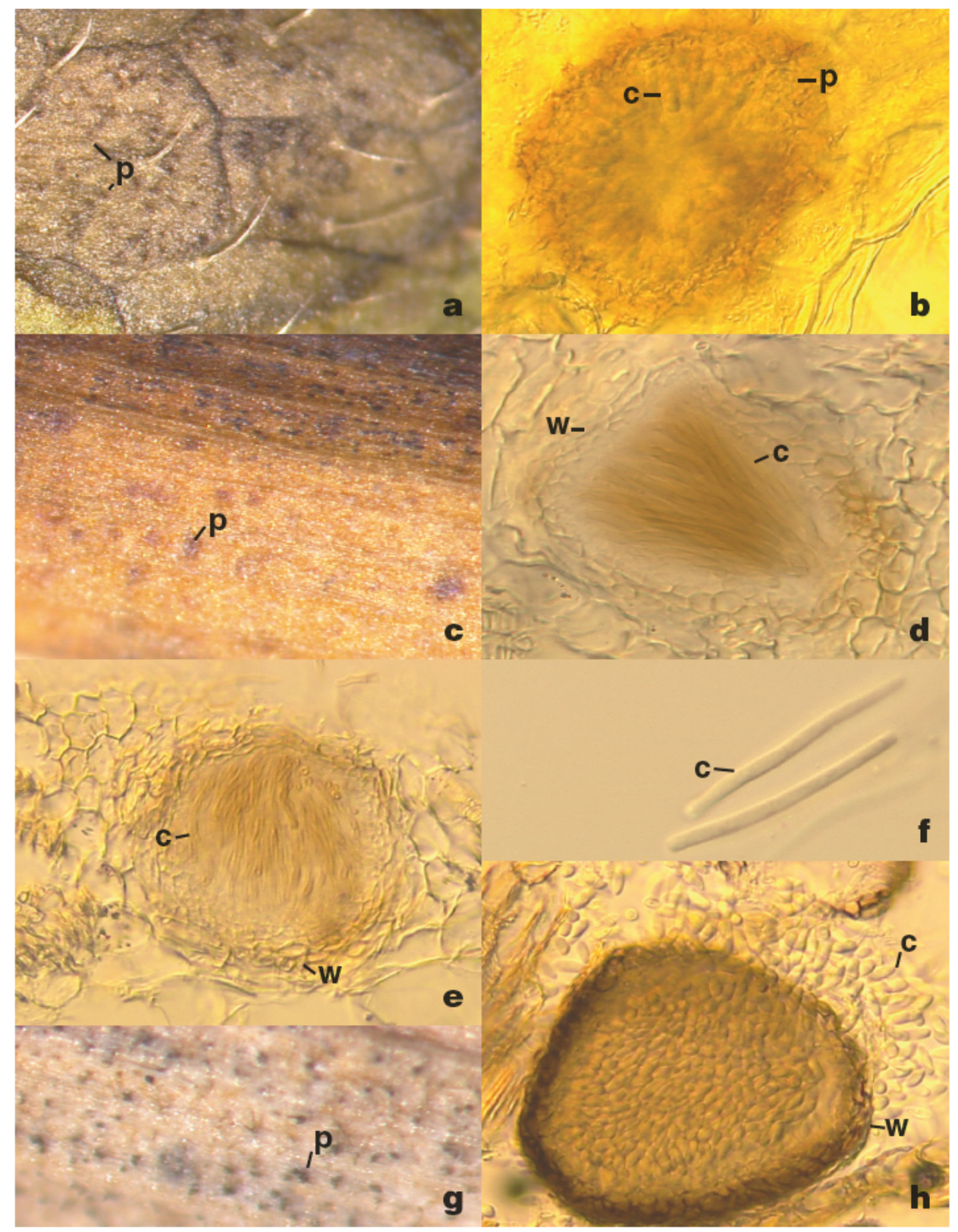

Fig. 2. Ascochyta geraniicola: pycnidia and conidia on a leaf of Geranium sylvaticum (a-b); Septoriella junci: pycnidium and conidia (c-f); Phyllosticta caricis: pycnidium and conidia ( $\mathrm{g}-\mathrm{h})$; c-conidia, p-pycnidium, w-wall of pycnidium. 